\title{
Nisei Politics of Identity and American Popular Music in the 1930s and 1940s
}

\author{
Susan Miyo Asai \\ Northeastern University
}

Growing nationalist thinking and anti-immigration legislation in American politics today calls for a critical historicizing of the continuing ambiguities of U.S. citizenry and notions of what it is to be an American. The identity crisis of Nisei-second generation Japanese Americansresulted from the complex intersection of America's racialized ideology toward immigrants, California's virulent anti-Asian agitation, and the economic and political power struggles between the United States and Japan in gaining dominance of the Pacific region.

For many Nisei music served to reinforce their American identity during the tense years leading up to World War II. Swing music, popular music of the day, sparked a dance craze during the 1930s and 1940s among young Americans. Because Nisei were coming of age during this period, I chose to study the influence of popular music on the formation of their identity. Interviews with West Coast Nisei about the role of music in their lives serve to test my premise. 
George Yoshida's book, Reminiscing in Swingtime: Japanese Americans in American Popular Music (19251960,) prompted this research. It is invaluable for analyzing the correlation between music and identity particularly of second generation Japanese Americans. In this study, I juxtapose the identity of Nisei as Americans born in the U.S. with the politics of prejudice that prevented this population from being socially accepted and exercising their political rights.

I address the formation of Nisei identity within the context of their rejection as citizens and the discriminatory injustices they endured. The particular sociopolitical circumstances Nisei faced elucidate how identities are created and manipulated to justify the treatment of citizens considered inassimilable and considered a threat in times of political conflict and impending war.

Development of the Nisei's identity demonstrates the impact of the social and political conditions in which this generation matured, and the challenges they faced in asserting that they were Americans. Highlighted is the importance of culture in evolving identities and the politics surrounding them. This politics of identity is a precursor to identity politics, a field of inquiry that emerged in the social revolution of the 1960s. ${ }^{1} \mathrm{~A}$ politics of identity stands apart from identity politics in that it does not emphasize difference as leverage for empowering identities, but instead stresses the goal of commonality in the desire to participate in U.S. national culture. Posing the questions "What historical and social forces from the 1900 s to the 1940 s shaped Nisei identity?" and "How did music serve as an expression of the Nisei's Americaness?" is meant to stir a discussion of the racial ideology inherent in American life and how music connected Nisei to the nation and culture in which they sought acceptance. 
The politics of identity frames the exigencies Nisei faced in attempting to assimilate into U.S. national culture and attain the rights of full citizenship prior to and during World War II. A politics of identity narrates Nisei experiences of racial discrimination and political exclusion from the 1920s on, climaxing in the internment of Japanese Americans primarily from the West Coast in the 1940s.

Cultural politics provides a useful framework for exploring the purpose of music in predominantly middle class Nisei life. Personal interviews with Nisei reveal whether American music, especially the dance band music of the 1930s and 1940s, was integral to the Americanization of Nisei or not. Lisa Lowe asserts that national culture is the arena in which an individual politically evolves into an American citizen: "It is through culture that the subject becomes, acts, and speaks itself as "American." (1990: 2-3). Although citizenship is commonly equated with meeting official requirements and laws, a fuller interpretation of American citizenship takes into account a certain ethos created by not only history, narratives, and events, but by language, customs, celebrations, and forms of artistic expression that contribute to the social and political fabric of this country. Culture is the means by which one personally identifies and establishes a relationship to the national collective. Stuart Hall talks about cultural identities as "not an essence, but a positioning. Hence, there is always a politics of identity, a politics of position." (Hall 1990: 226). In positioning themselves as Americans, Nisei became embroiled in a politics of identity that is historically based, involving how the United States viewed itself economically and politically as a nation and as an evolving world power.

The Nisei's search for an identity presents a complex and fluid process that involved not only the external racial predicament this generation faced, but also internal pressures they experienced within their communities. Forming an identity required a negotiation 
of their ethnic heritage, generation, occupation, and residential location in their desire to prove themselves American. Lon Kurashige in his book, Japanese American Celebration and Conflict: A History of Ethnic Identity and Festival in Los Angeles, 1934-1990, relates how Nisei sought to "smash" the stereotypes and perceptions white America had of them and dispel the widespread view of the role Japanese tradition and customs had in their daily life. By aligning themselves with the social practices and hierarchies in American society, they adopted the notions "that men and masculinity were privileged over women and femininity; middle-class lifestyles and sensibilities were valued over those of the subordinate classes; and faith in the fairness of the American government." Such ideas resonated with the Nisei's Japanese patriarchal upbringing and familiarity with class hierarchies (Kurashige 2002: 6). Japanese in America also drew on the social sensitivity of their cultural heritage-the ability to adapt and assume the attitudes and behavior of the host society in facilitating their acculturation (Fugita and O’Brien 1991: 94).

\section{Nisei Subculture}

The Japanese immigration pattern in the U.S. delineates three distinct generations as a result of the National Origins Act of 1924, which cut off further entry of this population until the 1965 Immigration and Nationality Act. The well-defined generations of Japanese Americans include Issei ('first generation')-mmigrants who arrived on American shores between 1885 and 1924; Nisei ('second generation')-Issei's offspring; and Sansei ('third generation') - the children of Nisei. Fourth and fifth generations succeed the third generation Sansei, many of them racially and ethnically mixed as Japanese Americans continue to marry outside their ethnic group.

The first generation to be born on American soil, but considered the second generation to have settled in the U.S., the Nisei embodied the hope of their Japanese 
immigrant parents in fulfilling the American dream of economic opportunity and political legitimacy. Born between 1910 and 1940, by 1920 Nisei comprised nearly twenty-seven percent $(29,672)$ of the total Japanese American population of 111,055 . In 1930 their numbers jumped to around forty-nine percent $(68,357)$ of the total population and in 1940, close to sixty-three percent $(79,642)$ of all Japanese Americans in the contiguous fifty states (Daniels 1988: 156).

A majority of Japanese Americans settled on the West Coast, the primary entry point for Asian immigrants coming to the U.S. In 1920, around sixty-six percent of the 111,055 total population lived in California. By 1940, when the total population increased to 126,947 , the number of Japanese Americans in California expanded to seventy-five percent $(73,296)$ of that total. Of the remaining population, fifteen percent settled in Washington and Oregon and only ten percent resided in Colorado, Utah, Idaho, or New York (Daniels 1988:156). Because of the high concentration of Japanese Americans residing in California much of the discussion here centers on the Golden State. Additional research is needed to accurately portray Japanese Americans elsewhere.

The Nisei were not a homogeneous group and instead represented a spectrum of identities. This generation comprise two basic subgroups: those who were born and raised in the U.S. and Kibei, Nisei born here but sent to Japan by their families for three or more years of education before returning (Hosokawa 1969: 296). Central to this study are the U.S. bred Nisei $(87.5 \%$ majority), since it is their Americanization in which the impact of American music will be viewed. Nisei identities also varied according to whether individuals lived in rural areas or urban centers. Those living in rural areas led more provincial lives in isolated farm communities, while Nisei urbanites had broader social experiences and tended to be more cosmopolitan. 
Nisei often lived in Japanese enclaves in both rural and urban areas with their Issei parents. While socially interacting with other Americans in public schools through to high school, once Nisei enrolled in college, social segregation was more marked.

Occupationally, most relied on Issei enterprises in Japanese enclaves, which formed in response to the inhospitable environment of the West Coast states. Nisei found employment as commercial fishermen, retail managers, wholesale managers, sales clerks, craftsmen, chauffeurs, domestic service workers, truck farmers, farm laborers, contract gardeners, and nursery operators and laborers (Kurashige 2002: 29). Many felt confined to their communities and could do little since positions in engineering, manufacturing, or education were closed to them and many businesses either had policies against their employment, or bowed to employees who refused to work alongside people of Japanese descent.

Although Nisei were economically middle class, they were socially and politically disenfranchised, making it difficult for them to mobilize in their quest for equality. Those who practiced law, medicine, or owned large retail businesses in the ethnic economy were of upper middle class status. Nisei proprietors of small retail businesses or wholesale produce operations fell centrally within the middle class. Others employed in domestic service, contract gardening, sales, farming, and other manual service work occupied the lower end.

\section{Enemies in Their Own Land}

Prior to World War II, white racism subordinated the West Coast Nisei in every aspect of their lives. Politically, they were denied full rights as citizens; economically, discrimination severely minimized their occupational opportunities; socially, they were ostracized and unwelcome in certain neighborhoods, public facilities, and social institutions; and racially, they were viewed as "base, inassimilable, and objectionable" (Ichioka 2006: 118). 
Politically, as legal citizens of the U.S., Nisei theoretically had an advantage over their parents who were regarded as aliens ineligible for citizenship. But the prevailing racial prejudice accompanied by prohibitive state and federal legislation severely limited economic and social opportunities for them. The anti-Japanese sentiment leveled at Nisei, historically, had its beginnings in the anti-Asian agitation against the Chinese, starting in the 1850s. Organized labor, economically motivated to eliminate competition for jobs with Chinese workers, cultivated anti-Asian attitudes in California state politics. They led the first two decades of anti-Japanese agitation when Japanese immigrants increased in number around the turn of the century. Their agitation made inevitable the federal immigration law of 1924 that prohibited further emigration of Japanese laborers.

Orientalism, a concept of "otherness" applied to people of Asian descent, is the underlying discourse that scarred the formation of a Nisei identity. An idea rooted in the European Enlightenment, orientalism reinforced the dichotomy of submission and dominance; the submission of Asian peoples by dominant European powers ${ }^{2}$ (Tchen 1994: 15). The ideological concept of nationality in the United States, based on Protestantism and an Anglo-Saxon heritage, shaped the idea of otherness referred to as American Orientalism. ${ }^{3}$ This form of Orientalism contributed to the social construction of a pejorative racial identity of Asians in this country and it explains the deep-seated prejudices toward and profiling of Asian immigrants even today.

Historically, ties between the U.S. and Asian countries have always been problematic. Causes for the uneasy relationship are the orientalist racializations of Asian countries as alien and barbarous; the perceived threat of Asian immigrant laborers as the "yellow peril" in supplanting white European immigrants; and the conception that Asians are physically and intellectually different, with a subtext of being inferior, and therefore inassimilable. (Lowe 1996: 4). 
What has negated Asian American assimilation into the national culture is the history of labor exploitation of this population within the economic sphere of American capitalism and U.S. victories in three wars in Asia in the twentieth century-the Philippines, Japan, and Korea. These developments contributed to the schizophrenic stance of the U.S. which excluded Asians for citizenship in order to maintain the Anglo-Saxon or Nordic national identity while keeping an open door to East Asian countries to ensure economic access and growth (Lowe 1996: 20).

Fanning the flames of discrimination and inequality were the perceived threat of Asian states as rivals both economically and militarily. Economic forces emerging in Asia challenged European and American dominance in the global economy from the nineteenth century. In his book Asian/American: Historical Crossings of a Racial Frontier, David Palumbo-Liu echoes how the emergence of the U.S. as a modern nation is intertwined with Asia in the politics of a "new global political economy" in the 1930s. He talks in detail about the fear of White America toward contact and intermixing with "racial minorities, the poor, and immigrants" in the early twentieth century $(1999,17,26)$. This fear focused on Asian immigrants as the U.S. pushed to politically and economically expand and control the Pacific region. Psychological and scientific discourses addressed and fueled White America's fear of the "Other." Eugenics, in particular, argued for "exclusion, deportation, imprisonment, commitment to insane asylums, anti-miscegenation laws, and forced sterilization" in reforming who could become an American ${ }^{4}$. Eugenicists set the standard in using race as an argument against immigration and played a central role in passing the anti-immigration National Origins Act of 1924. This act reinforced racialized notions of citizenship and nationality that accompanied U.S. social and economic interests ${ }^{5}$.

Further complicating the United States relationship with Asia was Japan's imperialistic intentions overseas in 
their search for territory and natural resources. Japan's invasion and conquest of Manchuria in 1931 and Nanking (capitol of Nationalist China) in 1937, created political and economic tension both in the U.S. and globally. The economic and military pressures affecting the U.S. created an inhospitable political culture for Asian immigrant laborers in the national economy, despite their necessity for economic growth. This ambivalence converged with political and legal views of Asians as culturally and racially "other," resulting in being ineligible for citizenship (Lowe 1996: 5).

Carey McWilliams ${ }^{6}$ in his book, Prejudice. JapaneseAmericans: Symbol of Racial Intolerance, describes the "undeclared war" between California and Japan between the years 1900 and 1941 (1944: 15). He frames the conflict as a transpacific struggle between Japan and the U.S. for political and economic dominance. First and second generation Japanese Americans were victimized in the push for white supremacy in California and Japanese supremacy in the Pacific. White supremacist groups in California, such as the Sons of the Golden West, the State Federation of Labor, the California Grange, and the American Legion used anti-Japanese sentiment as a means to solidify and unite their membership around the single issue of a common enemy-the Japanese immigrant. The reactionary fear of people who were racially and culturally different manifested in the mantra of "Yellow Peril," cementing anti-Japanese feelings from 1909 on with this pejorative stereotype 7 of Japanese immigrants (McWilliams 1944: 44). "Yellow Peril" embodied white people's fear that the influx of Asian immigrants signaled the beginning of an invading horde. For over forty years, the continual opposition to Japanese in California created a firm ideological basis for anti-Japanese sentiment as it was applied to almost all political, social, and economic problems.

Discriminatory state policies economically and socially subordinated Japanese immigrants in California. 
The Alien Land Acts in 1913 and 1920 in California, and similar statutes in twelve other states, prohibited first-generation Japanese immigrants from owning land due to their racialized status as "aliens ineligible for citizenship." Industrious Issei and Nisei farmers proved capable of turning fallow fields into verdant farmland, creating unwanted competition for white farmers. Legislating the Alien Land Acts eliminated the competition by restricting Japanese land ownership and agricultural activity. Asian immigrants also endured segregation in the form of anti-miscegenation laws, such as Section 69 of the California Civil Code, finalized in 1880, forbidding Asians from marrying Caucasian partners. Such social segregation reinforced the untouchable status of Japanese immigrants.

Prejudicial treatment extended to education as well. In 1905 the San Francisco Board of Education proposed sending all Asian children to separate public schools; fortunately the proposal never passed. Asian children, however, in the following towns in Sacramento CountyFlorin, Isleton, Walnut Grove, and Courtland-were segregated and sent to separate public schools. Nisei students living in urban centers faired better, but their social opportunities were still clearly restricted.

In following the American dream of economic opportunity, some Nisei attended colleges and universities with great success. Many graduates, however, found it nearly impossible to obtain employment outside their ethnic communities. Many engineering, manufacturing, or business firms created regulations against employing Japanese Americans on the basis of race. Denial of their citizen's rights and social ostracism, in general, made culture an important vehicle for Japanese Americans in strategizing new subjectivities and practices that countered their political, economic, and social marginalization (Lowe 1996: 22). 


\section{Nisei Tales}

The following personal accounts of Nisei provide a needed perspective in surveying music's role in the Americanization of Nisei. I originally interviewed several Nisei for this study, but due to the length allowed for this article, I have included only three. It is my plan to interview more members of this generation to obtain a broader sampling of the role American popular music played for Nisei in their youth. The three Nisei presented here are from Los Angeles, San Francisco, and Wapato, Washington. They represent a range of Nisei life as experienced in two different urban centers and one isolated rural community. Other considerations for their choice included portraying individuals from varying socioeconomic levels and gender perspectives.

The interviews gave me the opportunity to learn about my subjects' socialization and whether music, particularly American popular music, played any role in their lives. To these means I asked the following questions:

1. Where were you born and when? Did you grow up at this location? Describe your home life.

2. When you were growing up, was music a part of your life? Did you learn songs in school? What kinds of songs? What kind of music did you like? Who were your favorite artists? Did you sing or play an instrument? Did you sing or perform with a chorus, music ensemble or band of some kind? What meaning did music have in your life?

3. Was American popular music a part of your growing up? If so, what songs did you like? Which musicians or singers did you enjoy? Did you listen to and dance to the music of the big bands in the 1930s and 1940s? Which were your favorite bands? Which singers did you like? What radio shows did you listen to? Did you attend live music shows? Where and when? 
4. If you listened to, danced to, or played American popular music, what meaning did it have for you? What did participating in this music mean for you? Did you ever consider this music to be part of your identity as an American? Do you feel that American popular music was a means for Nisei to express their Americaness, their participation in American mainstream life? If you agree, could you articulate how it expressed Nisei Americaness? If you don't agree, could you mention why not?

The advanced age of my interviewees gave this study a sense of urgency in documenting their stories of what it was like to be Japanese American in the 1930s and 1940s. Their narratives portrayed not only the hardships they faced, but also a certain indomitable spirit that enabled them to establish some sense of well-being.

Some of the interviewees now live in Massachusetts and attend the annual $O$-shôgatsu ['New Year's'] celebration in Lexington, Massachusetts organized by Japanese Americans in New England. I am grateful to them for sharing their personal, sometimes bitter, accounts. Their quickly dwindling numbers make their stories all the more precious.

\section{George Yoshida}

George Yoshida planted the seed for this study. In his book he states, "Popular American music was an essential, pervasive influence in the Americanization of Nisei." [1997: 126]. Yoshida, himself, is a product of this influence, so my interview with him is particularly valuable. ${ }^{8}$

Yoshida was born in Seattle, Washington and raised there until he was junior high school age before moving to Los Angeles. He stressed that his Americanization took place over time and through a broad range of activities and influences, such as the music he listened to, danced to, and played, the food he ate, the sports he 
participated in, the games he enjoyed, and the role of Protestant churches in his East Los Angeles community. He remembered, "I brought salami or peanut butter and jelly sandwiches [to school] and learned to eat soup without slurping [considered acceptable in Japanese culture]. I was too embarrassed to bring Japanese rice balls for lunch. I also drank Coca-Cola." Sports was another activity that became a symbol of Nisei Americaness for Yoshida who participated with other Nisei at the YMCA and at school. The churches also played a major part in the Americanization of both Nisei and their Issei parents. Yoshida recalled how "The use of English in hymn singing, Bible readings, and Sunday school, and the exposure to western harmonies and melodies in church music Americanized us." This interviewee saw his Americanization as a broader process of enculturation into middle class American life.

Strongly identifying himself as American, he harbored a certain reticence toward Japanese culture while growing up: “I didn't enjoy traditional Japanese music and Buddhism was alien to me, it was more cultural than religious." As was the custom, however, he attended Japanese language school everyday after public school where, he remembered, "I learned reading and writing, Japanese songs, and also went to picnics called undokai where we exercised and played games and there was food." His connection to Japanese culture was obligatory, but it did not influence or compromise the strong identification he had of being an American.

Yoshida came from a musical family, his mother played church music on organ and his father sang American songs. He described his musical beginnings while in elementary school in Seattle: "I joined the Harmonica Club that played mostly Stephen Foster songs, such as "Old Folks at Home" and "Swanee River." Then around 1935 I heard Benny Goodman's band on the radio for the first time along with Lionel Hampton, Teddy Wilson, and other 
African American musicians. This music really appealed to me, and I started lessons on alto saxophone in junior high school." In 1939 while he was in high school, he and his friends gathered to listen to the big band recordings of Artie Shaw and Benny Goodman, "I went to a friend's garage with two other friends - me on sax, and the other two on piano and trumpet." Yoshida continued, "We heard Artie Shaw play "Begin the Beguine"; I bought the record and arrangement and we tried to play it." During this period Yoshida listened to a number of musicians, Duke Ellington, Tommy Dorsey, and singers Frank Sinatra, Billy Ekstine, who sang with the Earl Hines band, and Bob Eberle, a singer in Glenn Miller's band. Yoshida's saxophone playing days continued when he attended Los Angeles City College (LACC) and played in the school swing band. It was while attending LACC that he heard Duke Ellington's band live performing “Do Nothing Till You Hear From Me" being the most memorable. In reference to black musicians, Yoshida mentioned, "Race records kept white bands and black bands segregated." Although he was able to attend performances by black bands, the sustained segregation of race records generally resulted in the Nisei's access and emulation of the music of white bands. ${ }^{9}$

Yoshida kept up his saxophone playing days while he was interned in Poston, Arizona from 1942 on. He performed as a member of the Poston camp dance band, the Music Makers. Dancing was an important part of camp life, "A lot of dances were organized by the social clubs and the Music Makers provided the music." Yoshida reiterated the importance of music saying, "Big band was our [Nisei] music." Yoshida's participation in American popular music as both a musician and a jitterbug dancer reinforces this sentiment. This Nisei's enthusiasm toward and ownership of American swing affirmed the importance of this music for his generation. 


\section{Yutaka Kobayashi}

Yutaka Kobayashi is a native of San Francisco who grew up in Japan Town between Laguna and Sutter streets. ${ }^{10}$ The typical activities of an American teenager filled Yutaka Kobayashi's days during the 1930s and 40s. Quite athletic, he participated in sports: "Sports was a big part of my growing up. There were baseball teams, football teams, swimming, and track. I was on the track team and won my letter in track." He also enjoyed fishing and going to movies, "Movies were a big part of our lives because all we had were radios, no TV. The big thing for us were the Andy Hardy movies, featuring Mickey Rooney, Ann Rutherford, and Judy Garland, where they showed teenage parties and such. We all tried to emulate that; we had our parties. The series lasted four or five years; it captured everyday life. Everyone emulated the characters and lifestyle in these movies." Kobayashi's interests and activities reflected those of any young person growing up in a middle class American family.

The church in his community played an important role in Kobayashi's socialization: "My two older brothers and I were active in our various social clubs, including a church fellowship club, which was a big thing Presbyterian - at Christ's Church on Post and Octavia. They held Sunday fellowship meetings with people in Berkeley and San Mateo. They also used to have so-called Christian conferences. Fellowship clubs served as a social outlet for Nisei." Annual Christian conferences offered opportunities to talk about social issues-international and evangelical-and included speakers as well as dinners and social dances. For Japanese Americans, churches were centers for not only social activities, but for employment and housing assistance as well.

The local YMCA also created social opportunities. Kobayashi attended the YMCA's annual New Year's Eve dances. The dances featured live music by local Nisei dance bands; there was one band in San Francisco that played at all the big events, but Kobayashi could 
not recall its name. Other local Nisei social clubs also organized their own dances. "These dances were a big deal. Whenever there was a dance planned it took about a month ahead of time [to plan it]-Spring Dance, Halloween Dance, Thanksgiving Dance-whatever a social club could afford." Kobayashi danced a lot and loved to jitterbug. To learn to jitterbug he explained, "One watched movies, practiced with a chair to learn jitterbug steps and moves. Jitterbug dancing involved a 6-beat dance rhythm in half time (2/4). American dance music was an integral part of our Americanization. When we became teenagers in high school, we always looked forward to that [social life] because of the restricted home life. We never invited girls to our house. We only socialized at church, school, or at clubs, that was it, or if you happened to meet in a store. Those were the only social outlets in terms of meeting the opposite sex as a teenager. You could hardly ever invite friends of the opposite sex to your house. You just didn't do that. It was a problem with your parents [who would ask] "Why do you want to visit, what's on your mind?" So, dancing became a very important part of our lives, we always looked forward to that. Music was a big part of our lives, because when we were growing up, being the first generation of Americans, we wanted to be Americans and act like Americans even though we didn't look like Americans. We did everything that the Americans did, the white guys did." Dances, the primary social activity for all teenagers, were the focus for many Nisei.

Kobayashi confirmed that the popular bands of the time included those of Tommy Dorsey, Jimmy Dorsey, Lionel Hampton, and Count Basie. Popular singers included Kate Kaiser, Ted Weems, and Sammy Kaye. Radio was the primary purveyor of the latest hit tunes on national programs such as "Major Bowe's Amateur Hour," which was one of the most popular programs broadcast in the U.S. in the 1930s and 1940s. "All of us knew the top ten hit parade songs. We knew all the artists. When I was growing up I thought Bing Crosby was the big guy. 
Eventually, I changed to Frank Sinatra." He also heard music live: "In San Francisco the Golden Gate Theater, down at Market and Golden Gate streets, used to have a stage show. I saw a lot of performances; Frank Sinatra used to appear, the Benny Goodman band and others. In the 30 s people like Sinatra, the big bands all performed in movie theaters. After the movie a band would play a set or two, a juggler would come out, magicians would do card tricks, and someone would do acrobatics. It was expensive [to go to these shows]. In Chicago they did the same thing, and of course the Paramount Theater in New York was famous for having Frank Sinatra." It is clear that both listening to music and dancing were central to this Nisei.

In contrast to the many Americanizing influences in his life, Kobayashi's home life was traditionally Japanese. Kobayashi's family celebrated $O$-shôgatsu [New Year's] every year. O-shôgatsu lasted a week or longer. "My mother cooked up a ton of food and then friends would come over and drink sake and whatever else. Everyone would eat special foods - o-mochi (rice cake). We looked forward to it because of the food." Nisei were expected to attend Japanese school, where they learned to read and write Japanese. They also learned about customs and social obligations as a means to connect them to their heritage. Kobayashi and his two older brothers went, but he rebelled saying, "I am an American, why do I have to go to Japanese school?" He never graduated from Japanese school while his two brothers did. Many Nisei experienced home life rooted in Meiji Japan, but when they left their homes to go to school or be with their friends, their American persona prevailed.

\section{Hisayo Asai}

In contrast to urban Nisei, Yoshida and Kobayashi, Hisayo Asai's personal account tells the experience of Nisei residing in rural areas. ${ }^{11}$ This interviewee was born in 1920 and raised in Wapato, a very small farming town 
in the central part of Washington. Wapato was a mixed community where twenty-five percent of the population was Japanese. Most of the Japanese population were farmers and families who lived outside of town in the outlying areas. Asai's family were not farmers. "My father was a very successful businessman who worked with the farmers packing and shipping [produce]. He had a large warehouse and employed many people, so our life was very comfortable."

Asai's home life was basically American: "We were the only Japanese family in a white community. Our home was just as nice as the others, it was just that we looked different. Our life was very American because we just went along with everything else in the community. We lived just like our neighbors. Both my mother and my father spoke English because they were living in a white community. I think my mother felt a little more comfortable speaking Japanese, but she spoke both Japanese and English." Asai's family conformed to middle class American customs in their attempt to assimilate.

While many aspects of daily life reflected middle class American living, Asai's connection to Japanese culture and the community remained vital. Well-defined segregation in Wapato forced the creation of a separate Japanese community. Her father did quite well as a businessman and he provided financial assistance to many Japanese families. On New Year's, many of the families he helped visited to thank him for his favors. Hisayo's father was an important leader in the Japanese community, and when Japanese Americans were interned during the war, he was sent to a separate Department of Justice camp exclusively for community leaders. While her family ate mostly American food, Asai reminisced how, "Occasionally my mother would make Japanese food, which I loved more than American food. I was always very happy when New Year's came because my mother cooked a feast of $o$-Shôgatsu food. There was a Japanese store in the community and they got all the food shipped over." 
Japanese language use, although not actively practiced at home, was a daily activity. Her parents spoke Japanese to each other and Asai went to a Japanese after school program every day until the sixth grade.

Asai gave an account of a social life quite different from Nisei urbanites. The more intense anti-Japanese sentiments in rural farming areas, due to race and the economic competition between Japanese and white farmers, created a very restricted social environment for Nisei youth. Racism severely curbed the social activities of Asai and her age group. When asked about dances and social activities in school Asai answered, "We didn't go. They must have had dances, but we didn't go. We never went to the prom." The Methodist and Buddhist church in Wapato didn't have youth fellowship groups since many people lived far away; there were no organized social activities for Nisei youth. Also, in the rural areas there were no YMCAs or YWCAs, which served as important centers of sports activities and social dances for Nisei who lived in urban centers.

In response to their barren social lives, Nisei youth in Wapato focused on their studies, sports, or the arts. Asai directed her energies toward playing European classical music on the piano, "I was given piano lessons ever since I was six years old. I had two younger sisters and they all had music lessons, but I am the only one that pursued it because I liked it. And so, home life for me was go to school, come home and practice. I did my homework and practiced again. I liked it. We couldn't do a lot of things, so most of the people would just accept it and knew what we could do. I know in many other communities people could take part in sports teams and so most of the communities had their own Japanese sports teams I think mostly baseball. School was very important. We couldn't go to a lot of things so the children just studied. We all did very well in school." For Asai, pursuing piano performance filled her hours and days; a way to transcend her circumscribed life. 
Performing classical music was Hisayo Asai's identification as an American. For young American women, playing piano was both a source of cultivation and parlor home entertainment. In school, she was active as an accompanist for the high school chorus and in Wapato as a soloist for various ladies' club gatherings. Asai commented on how playing piano was her entrée into the mainstream community in her hometown, "I was in demand in the community. They had women's groups who would have meetings and they asked me, "Would you play a solo? They had different clubs, they had garden clubs and different kinds of social clubs. They wanted something to add to their program. I was forever going from one place to another just volunteering. They would ask and I would go. Through my high school years that was very important to me. I enjoyed it. So, I was part of the community and it softened the racism."

As for American popular music, Asai recalled, "I really liked popular music. I wasn't too aware, but I knew which songs were popular at the time. I was so ingrained with classical music that I liked; I practiced so much that I really didn't have time to listen." Asai's involvement with American popular music was minimal; it wasn't until the war and her move to New York City that this music played a greater role for her. She danced at social gatherings hosted by the Japanese American Citizens League where she met and married Woodrow Asai, my father's youngest brother.

\section{Conclusion}

Recounting how young Americans of Japanese descent listened to, danced to, and even performed popular music of 1930s and 40s America illustrates the importance of culture as an avenue for Nisei in cultivating their Americaness. George Yoshida contends that a common reaction of Nisei to their predicament was to attempt to assert one's identity as an American 
as strongly as possible, often through music. Lowe echoes the Nisei's response: "Where the political terrain can neither resolve nor suppress inequality, it erupts in culture." (1996: 22). It is clear that music contributes to the ethos of a national culture, and as such it can be considered a marker of identity. Popular music's social function among American youth had a dual meaning for Nisei. While music as an accompaniment to dance was an integral part of their social lives, it was also a tacit way for Nisei to reinforce their identity as Americans. Yoshida's statement, "We didn't seek to be Americans, we were Americans. We totally immersed ourselves in American culture" expresses the emphatic way in which some Nisei regarded themselves. Politically, the Nisei's positioning was assimilationist; culturally, they strove toward whiteness-mainstream society's Eurocentric standard of Americanness. Whiteness was the ideal as expressed by Lily Oyama Sasaki in Sacramento in 1930:

We all wanted tobe blond and blue-eyed Americans, hated to be Japanese.

We changed our Japanese names into American names. Were criticized for our short hairdos, but didn't care. Went to movies, were crazy about Clara Bow and Joan Crawford! Loved jazz...Red Nichols and the Five Pennies,

Paul Whiteman 'The King of Jazz,' and clarinetplaying Ted Lewis; loved the vocals of Connie Boswell and Ruth Etting. (Yoshida, 1997: 4)

A line of inquiry not directly included in the interviews, but important to the identity of the succeeding Sansei generation, was the influence of African American music in Nisei life through American popular music. From the 1920s on, black and white musician composers borrowed from one another in developing popular music in the United States. In the 1930s and 1940s, black and white big bands played swing, a genre that stylistically combined Tin Pan 
Alley and jazz. In this way, African American jazz entered the sphere of American popular music and many Nisei listened and danced to it. In-depth research needs to be conducted on this topic, but a few ideas can be inferred from Nisei statements about music during the 1930s and 1940s. Blackness did not appear to play a direct role in the development of Nisei identity. The interviewees in this study named mostly white singers, bandleaders, and big bands that were all the rage in their youth. Yoshida expressed the most interest in black musicians, mentioning that he listened to bandleaders, Duke Ellington, Lionel Hampton, and Jimmy Lunceford, and singers, Billy Eckstine and Sarah Vaughn. Kobayashi also included Lionel Hampton and Count Basie as popular bandleaders. Yoshida talked about how black music, produced and sold as 'race records' from 1921 to 1942, was marketed to black audiences and were not intended for the rest of the population. He also mentioned that arrangements of the black bands were not available. Contributing to the popularity and reach of white bands and musicians were the amount of exposure they received on popular radio programs-the same programs that exposed Nisei to the latest hits. The continuing disenfranchisement of African Americans also deterred Nisei from considering blackness as an avenue for climbing the social, political, and economic ladder to greater acceptance and mobility. The hegemonic pull of Euro-American mainstream culture appears to have shaped Nisei in idealizing whiteness.

The interviews point to American popular music as having a role in Nisei life, but to varying degrees. A major factor that influenced the degree of importance of popular music was the interviewee's socialization, which was dictated in large part to whether they lived in an urban or rural setting. The two interviewees raised in urban centers, Yoshida and Kobayashi, had very active social lives due to the larger Japanese American communities whose institutions facilitated social activities. Swing band dance music played a much greater role in the social lives 
of these urban dwellers. The association of swing music with dancing and socializing gave popular music its power and appeal. Popular music played a much smaller role, however, in the life of the third interviewee, Asai, who grew up in an isolated rural community. Racist attitudes in her town prevented her from having much of a social life, limiting her exposure to and enjoyment of dancing to popular music. Interviewing Asai also revealed that European classical music was important particularly to young Nisei women in emulating middle class Americans. American popular music proved to be one avenue for assimilating into the national culture; future studies need to consider a wider variety of music to better measure the impact music had in Americanizing Nisei. The Nisei interviewees recalled learning Stephen Foster songs and spirituals in school, hymns in church, and campfire songs.

From the interviews we learn that music was only one facet of the Americanization process. Going to the movies, playing games and sports, attending church services, and learning in school were all part of a Nisei's enculturation. Here again, the degree of enculturation varied according to the individual. Nisei lived culturally split lives and some families were more assimilated than others. The differing degrees of enculturation present a complex picture. Choosing music as a reference point for measuring the Nisei's Americanization is only one way from which to view the whole process, but it offers a clear idea of what music meant to them and why.

Tragically, despite Nisei efforts to insert themselves into the national culture, racist conceptions of nationality created insurmountable barriers. The physiological and cultural differences of Asian immigrants and their offspring proved to be too far a field from the Nordic/ Anglo-Saxon mold of the late eighteenth century when the foundation for American nationality formed. Then, in the late nineteenth and early twentieth centuries economic and political challenges facing the U.S. as an evolving world power perpetuated nativist sentiments 
that shaped immigration policies that were exclusionary, rearticulating racial boundaries of nationality that continued to bar non-whites.

My intent is not only to particularize about the failure of Nisei in their efforts to achieve a national identity through music, but also to present a larger picture that is critical of American nationalism and who is allowed to fully belong. The National Origins system of immigration preferences and quotas, which ended Asian immigration after 1924, was repealed by the passage of the 1965 Immigration \& Nationality Act. Echoes of the racist quotas of the National Origins system, however, still reverberate. In the 1965 legislation, countries in the western hemisphere were not subject to any quotas; a quota of 20,000 has subsequently been legislated as a result of heightened security. Meanwhile, countries in the eastern hemisphere have always had a quota of 20,000 (http://www.asian-nation.org/1965-immigrationact.shtml). The continuing use of quotas for populations from the eastern hemisphere permanently registers the undesirable status of people who have been racially set apart. Such ideological bias remains a barrier to national citizenship for a variety of people who seek to make the U.S. their new home. Becoming an American is still a challenge that involves countering historically based biases and racial attitudes.

It is the travails of the Nisei that pushed the next generation of Japanese Americans toward an identity politics, calling for a greater acknowledgement of their Japanese heritage as a source of strength, and a pledge to humanity to fight for the rights of people also considered "other." Rejection of the Nisei pointed the way for many third generation Sansei in seeking alternatives and choosing a separatist politics. This new direction led to the creation of the Asian American political movement in the late 1960 s into the 1970s. Today, even as citizens, Asian Americans continue to be culturally and racially situated outside the boundaries of the nation. This continuing 
legacy of racialization and the enduring anti-immigrant sentiment in the U.S. speaks to the need for a more inclusive society and movement toward a humanism that recognizes merit and worth over skin color and heritage.

\section{Notes}

${ }^{1}$ R. Brunt, "The Politics of Identity" in New Times. The Changing Face of Politics in the 1990s. Ed. S. Hall and M. Jacques (London: Lawrence and Wishart, 1989); C. Fusco, "Passionate Irreverence: The Cultural Politics of Identity" in Art Matters. How the Culture Wars Changed America. Ed. Brian Wallis, Marianne Weems, and Philip Yenawine (New York/London: New York University Press, 1999); P.Gleason, "American Identity and Americanization" in Concepts of Ethnicity (A Series of Selections from the Harvard Encyclopedia of American Ethnic Groups), Ed. S. Thernstrom (Cambridge, MA/London: Belknap Press of Harvard University Press, 1980); S. Hall, "Cultural Identity and Diaspora" in Identity: Community, Culture, Difference, Ed. J. Rutherford (London: Lawrence and Wishart, 1990); R. Jenkins, "Rethinking Ethnicity: Identity, Categorization and Power" in Ethnic and Racial Studies 17, no. 2 (1994); L. Lowe, Immigrant Acts: On Asian American Cultural Politics (Durham/ London: Duke University Press, 1996); D. Palumbo-Liu, Asian American Historical Crossings of a Racial Frontier (Stanford, CA: Stanford University Press, 1999); E. W. Said, Orientalism (New York: Vintage Books, A Division of Random House, 1978/1994); E. Zaretsky, "Identity Theory, Identity Politics: Psycholoanalysis, Marxism, Post-structuralism" in Social Theory and the Politics of Identity, Ed. C. Calhoun (Oxford, UK/Cambridge, MA: Blackwell Press, 1994).

${ }^{2}$ There is a precedent for orientalist racializations early on in the development of the ideological basis of American identity. Between 1776 and 1815 there was a predisposition toward defining the concept of nationality ethnically along Anglo-Saxon lines. Also during this time, American political ideology formed from "abstract ideals of liberty, equality, and republicanism" drawn from the European Enlightenment. The universalist ideology of American nationality was in theory open to anyone without regard to an individual's "national, linguistic, religious, or ethnic background." This idea formed within the context of the late $18^{\text {th }}$ century when eighty percent of white Americans were British. This majority coupled with a "latent predisposition" to defining the concept of nationality from the perspective of ethnicity resulted in a contradictory view that regarded other racial and cultural groups-blacks or Indians-as "falling outside the range of American nationality" (Gleason 1980: 62-63). Blacks and Indians, therefore, were excluded and only free white people were eligible to become citizens without any regard for their national background or native language. Nativist sentiments became stronger after 1830 when massive migrations from Europe began. American national identity faced a number of challenges in coming to terms with the different religions, politics, education, and culture of the four million immigrants who landed on American shores between 1830 and 1855 (Gleason 1980: 68-69). The American response to this deluge of people who fell outside the Anglo-Saxon mold brought religious and stronger ethnic considerations into the national identity equation. From the 1890 s to the 1920 s the debate about restricting immigration marked the reversal of the country's original open door policy to immigrants and a growing intolerance of immigrants' perpetuation of their nationalities while living on American soil. World War 


\section{Asai-Nisei Politics of Identity and American Popular Music}

I raised ethnic antagonisms, resulting in immigration restriction laws when the war ended. From the 1900s to the 1920s an Americanization movement stressed the assimilation of immigrants who were expected to conform to mainstream American culture, language, religion, and manners (Gleason 1982: 79, 85).

${ }^{3}$ For a fuller description of the Protestant, Anglo-Saxon Orientalism, which I refer to as American Orientalism, see John Kuo Wei Tchen's article "Believing is Seeing: Transforming Orientalism and the Occidental Gaze" in Asia America: Identities in Contemporary Asian American Art. Tchen discusses how Westerners have been enculturated to view the Asian body and other physical features from the perspective of the "Orientalist socialization" of nineteenth century American commercial culture. Within this context, he introduces the social construction of "yellowface," describing it as a means for Asians to assimilate into mainstream society.

${ }^{4}$ After 1900 scientific racism's promotion of the superiority of the Anglo-Saxon and Nordic races and the assumption that cultural traits were genetically passed on along with physical attributes fed American xenophobia. The science of eugenics furthered such racialized thinking with the view that "the indiscriminate mixing of races was more likely to result in cultural debasement than cultural improvement." Madison Grant's The Passing of the Great Race (1916) extolled Anglo-Saxonism, systematizing and further influencing racializations that played an important role in restrictive laws of the 1920s (Gleason, 1980: 94). The coupling of "orientalist racializations" of Asians as inassimilable and attitudes of "Anglo-Saxon" or "Nordic" racial superiority gave rise to Asian immigration exclusion acts and laws against naturalization in 1882, 1917, 1924, and 1934 (Lowe 1996: 5; Kitano and Daniels 1988: 13). The Immigration Act of 1924, in particular, pointedly applied a national-origins quota system that ended Asian immigration for forty-one years. Repeal of these exclusionary laws, between 1943 and 1952, granted Asian immigrants the right to citizenship. However, the almost onehundred-year period of racist restrictions politically disenfranchised Asians, and only today do they have a significant political presence.

${ }^{5}$ For greater detail about how racial ideologies and economic interests impacted the formation of "modern America," and how Asian immigrants figured into that national body, read the well-researched work Asian/American: Historical Crossings of a Racial Frontier by David Palumbo-Liu, which I have cited above in the body of the text.

- Carey McWilliams, born in 1905 in Steamboat Springs, Colorado, was a lawyer who championed the causes of minorities in his many articles published in periodicals and newspapers in Los Angeles. In 1939 he was appointed California Commissioner of Immigration and Housing, a position he held until ousted by governor Earl Warren in the early 1940s. He received national attention with two books-Factories in the Field and III Fares the Landthat narrated the problems and difficult life of migrant laborers in nearly three fourths of the U.S. The work by McWilliams cited above-JapaneseAmericans: Symbol of Racial Intolerance-presents a detailed case history of the mistreatment of this racial minority, and poses a question to American citizens: "What shall we do to solve our fundamental problems at home?" This question is still being asked today. 
${ }^{7}$ There is a growing body of research about the Asian American body and the impact it has had and continues to have on how Asian Americans are viewed and received on a visceral level. Elena Creef's book on Imaging Japanese America: The Visual Construction of Citizenship, Nation, and the Body is an insightful study of the "distinct visual rhetoric in the symbolic and cultural representation of Japanese Americans in the mid-to late twentieth century, where the racist hysteria of World War II unjustly framed this ethnic community as disloyal citizens of the nation." Creef analyzes a broad range of visual and "textual" material making it very useful for delving into the visceral aspects of difference.

${ }^{8}$ George Yoshida, interview with author, San Francisco, California, 30 March 2006.

9 The Nisei's emulation of white bands is an important point, but it was not a part of my initial inquiry. I intend to include this line of questioning in future interviews with Nisei. The idea of white vs. black music influence on Nisei is discussed briefly in the conclusion.

${ }^{10}$ Yutaka Kobayashi, interview with author, Wellesley, Massachusetts, 13 June 2006.

${ }^{11}$ Hisayo Asai, interview with author, New York, New York, 31 August 2006.

\section{Works Cited}

Brunt, Rebecca. "The Politics of Identity." In New Times. The Changing Face of Politics in the 1990s. London: Lawrence and Wishart, 1989.

Daniels, Roger. Asian America: Chinese and Japanese in the U.S. since 1850. Seattle/London: University of Washington Press, 1988.

Fugita, Stephen S. and David J. O’Brien. Japanese American Ethnicity: The Persistence of Community. Seattle: University of Washington Press.

Gleason, Philip. "American Identity and Americanization." In Concepts of Ethnicity (A Series of Selections from the Harvard Encyclopedia of Ethnic Groups). Ed. Stephan Thernstron. Cambridge, Massachusetts: Belknap Press of Harvard University Press, 1980.

Hall, Stuart. "Cultural Identity and Diaspora." In Identity: Community, Culture, Difference. Ed. Jonathan Rutherford. London: Lawrence and Wishart, 1990.

Ichioka, Yuji. Before Internment: Essays in Prewar Japanese American 
History. Ed. Gordon H. Chang and Eiichiro Azuma. Stanford, California: Stanford University Press, 2006.

Kurashige, Lon. Japanese American Celebration and Conflict: A History of Ethnic Identity and Festival in Los Angeles, 19341990. Berkeley/Los Angeles/London: University of California Press.

Lowe, Lisa. Immigrant Acts: On Asian American Cultural Politics Durham/London: Duke University Press, 1996.

McWilliams, Carey. Prejudice. Japanese Americans: Symbol of Racial Intolerance. Boston: Little, Brown, and Co., 1944.

Modell, John. The Economics and Politics of Racial Accommodation. The Japanese of Los Angeles 1900-1942. Urbana/Chicago/ London: University of Illinois Press, 1977.

Palumbo-Liu, David. Asian/American. Historical Crossings of a Racial Frontier. Stanford, California: Stanford University Press, 1999.

Tchen, John Kuo Wei. "Believing is Seeing: Transforming Orientalism and the Occidental Gaze." In Asia America. Identities in Contemporary Asian American Art. Catalog to the exhibit, guest curator, Margo Machida, 13-25. New York: The Asia Society Galleries and The New Press, 1994.

Yoo, David. Growing Up Nisei: Race, Generation and Culture among Japanese Americans of California, 1924-49. Urbana: University of Illinois Press, 2000.

Yoshida, George. Reminiscing in Swingtime: Japanese Americans in American Popular Music (1925-1960). San Francisco: National Japanese American Historical Society, 1997. 